\title{
Taşlıcalı Yahya Bey’in Şehzâde Mustafa mersiyesine ontolojik analiz metoduyla bir bakış
}

\section{Muhammed Felat AKTAN 1}

\begin{abstract}
APA: Aktan, M. F. (2020). Taşlıcalı Yahya Bey’in Şehzâde Mustafa mersiyesine ontolojik analiz metoduyla bir bakış. RumeliDE Dil ve Edebiyat Araştırmaları Dergisi, (19), 398-412. DOI: 10.29000/rumelide.752374.
\end{abstract}

$\ddot{O} \mathbf{z}$

Klasik edebiyatımızda şerh geleneği yüzyıllardan beri devam eden bir süreçtir. Şârihler belli bir gelenek çerçevesinde eserleri yorumlamış, divan şiirlerini geleneksel şerh metoduyla açıklamışlardır. Günümüzde ise modernizm ile birlikte edebiyatta birçok kuram oluşmuştur. Bu teorik kuramlar edebiyata yeni boyutlar kazandırmış, daha sonra pratiğe dökülerek edebî metinlere farklı yaklaşılmasına zemin hazırlamıştır. Bu yeni yaklaşımlardan biri de ontolojik analiz metodudur. İlk defa Roman Ingarden tarafından uygulanan bu metotta varlık tabakalarının sanat eseriyle ilişkisi irdelenmiştir. Metin merkezli bir teknik olan bu yaklaşımda, sanat eserinin mevcudiyetinden yola çıılarak metin-okuyucu ilişkisi, estetiğin kapsamı irdelenirken katmanlara işlevsellik ve klasik şerh yöntemine farklı bakış açısı kazandırma bu tekniğin başlıca felsefî hedefleri olmuştur. Çalışmamızda Taşlıcalı Yahya Bey’in Şehzade Mustafa için yazmış olduğu mersiyeyi bu metotla inceleyeceğiz. Ontolojik metodun gelişimi, içeriği ve pratiği hakkında bilgi verildikten sonra Yahya Bey'in Şehzade Mustafa Mersiyesinin birinci bendini bu metotla analiz edeceğiz. Mersiyedeki birinci bentten yola çıkarak şairin psikolojik dünyası, semantik bölümü, kelimelerin algısal olarak karşılığı obje ve karakter imajı ve son olarak da kader katmanı eserde tetkik edilen belli başlı konulardır. Mezkur bölümler incelenirken klasik şerh yöntemindeki bazı uygulamalar ile uyumlu olduğu, bu yöntemin klasik şerh ile birçok ortak temasının olduğu görülmüsştür. Edebi sanatların ele alınışı, metnin nesre çevrilmiş hali ve şiir tahlilinden önce verilen metin ile ilgili teknik bilgiler bunlardan birkaçıdır.

Anahtar kelimeler: Şerh, Şehzade Mustafa, ontolojik analiz, mersiye

\section{The dirge of Prince Mustafa of Taşlıcalı Yahya Bey a view through ontological analysis method}

\begin{abstract}
Commentary tradition in our classical literature is a process that has been going on for centuries. The commentaries interpreted a certain tradition interpretation works and explained the poetry poems with the traditional commentary method. In contemporary, he is in literature together with modernism. These theoretical theories brought new dimensions to literature, and later, a different approach ground was prepared for literary texts. One of these new approaches is the ontological analysis method. The first assumed is used by Roman Ingarden. In this method, the relationship between paper layers and the artwork is examined. In this approach, which is a text-based technique, the text-reader relationship is based on the functionality of the layers and the classical annotation method, while examining the scope of the aesthetics, in order to derive from the existence of the artwork.This method will examine the dirge that Yahya Bey wrote by Prince Mustafa. Yahya Bey will

1 Arş. Gör. Dr., Dicle Üniversitesi, Edebiyat Fakültesi, Türk Dili ve Edebiyatı Bölümü (Diyarbakır, Türkiye), muardaf@hotmail.com, ORCID ID: 00oo-0002-6052-969X [Makale kayıt tarihi: 25.03.2020-kabul tarihi: 20.06.2020; DOI: $10.29000 /$ rumelide.752374]
\end{abstract}


analyze the first sub clause of Prince Mustafa mersiah with this method. Based on the first paragraph in dirge, the psychological world of the poet, the semantic part, the perceptual equivalent of words, the object and character image, and finally the layers of destiny are the main subjects examined in the work. By examining the mentioned sections, it is seen that this method is compatible with the applications related to the classical annotation method, and this method has a common theme with the annotation. Handling of literary arts, translating the text into prose and technical information about the text given before poetry analysis are some of them.

Keywords: Interpeation, Prince Mustafa, ontological analysis, dirge

\section{Giriş}

Asırlardan beri süregelen bir edebî gelenek olan klasik edebiyatımız, daha çok manzum ağırlıklı eserlerden oluşur. Bundan dolayı divan edebiyatının, içerisinde taşıdığı anlam ve mefhumların toplum tarafından anlaşılması için çözümlemeye ve tahlile gereksinimi duyulmuş, bu ihtiyaçla birlikte divan edebiyatında şerh geleneği doğmuştur. Klasik şerhin yanında yakın zamanda ortaya çıkan edebiyat kuramları, klasik şiirimizin yeniden yorumlanmasına, farklı bir bakış açıdan bakmaya sevk eder.

Günümüzde Göstergebilim, Anlambilim, Psikanalitik Kuram, Rus Biçimciliği, Hermeneutik ve Ontolojik Analiz yaklaşımlarının kullanımı metinleri tahlil etmede yeni boyutlar kazandırır. Edebî metne modern yaklaşımlar, edebiyat biliminin gelişmesine ve sonuç olarak edebî metnin farklı biçimlerde ele alınıp yorumlanmasına katkı sağlar. Modern yaklaşımlar muhtelif değerleri merkeze alarak edebî metni yorumlarlar. Söz gelim Yapısalcılık ve Rus Biçimciliği yöntemleri “eser”i merkeze almış okuru dikkate alır. Rus Biçimciliğinde metni oluşturan ögeler ön planda olurken, Hermeneutik yaklaşımında okur merkezli yaklaşım ön plandadır. Göstergebilimde gösterge sisteminin işleyişi ele alınırken, psikanalitik kuramda yazar merkezli bir yaklaşım söz konusudur.

Ontolojik yöntem son yllarda sıkça başvurulan metin tahlil tekniklerinden biridir (Bingöl,2019:144). Modern şiir çözümleme yöntemlerinden biri olan ontolojik analiz metodu metni çeşitli tabakalara ayırarak bu tabakları farklı biçimlerde çözümler. Bu analizden gaye, edebî metnin sanat değerini ortaya koymaktır. Ontolojik inceleme metoduna göre şiir incelemesinde eserin değerini ve şiirselliğini korumak gerekir.

Bir eseri incelemede temel amaç, o eserin ve yazarının değerini ortaya koyabilmek içindir. Şiir ve nesir çözümleme yöntemlerinden biri olan ontolojik inceleme metoduyla sistem içinde bir bütünlük oluşturan ses, kelime, anlam gibi unsurlar ayrı ayrı düşünülerek sistem içine dâhil edilmektedir. Yani ayrı ayrı olan tabakalar, bir bütünü oluşturmaktadır. Bu varlık tabakaları sayesinde şairin şiirinde ne anlatmak istediğini kolaylıkla anlaşlabilir. "Tabakalar düşüncesini estetikte ve edebiyat eserinde ilk uygulayan Roman Ingarden olmuştur. Çeşitli tabakalardan oluşan sanat eserini bir bütün olarak ele alan ve ona estetik bir gözle bakan Roman Ingarden'e göre sanat eseri çeşitli varlık tabakalarından oluşmuştur. $\mathrm{Bu}$ varlık tabakaları birbirleriyle uyum içinde ve iç içe geçmiş bir şekilde sanat eserinde mevcuttur. Onlar sanat eserinde bir bütünü oluşturmaktadır.” (Tunalı, 2002: 89).

Ontolojik analiz yöntemini, tek tek beyitler/dörtlükler üzerinde uygulamak mümkün olacağı gibi, bütün bir gazel/şiir üzerinde de uygulanabilir. Divan şiirindeki örnekler, bu yöntemin her iki açıdan da uygulanmasına müsait yapıdadırlar (Bayram ve Erdemir, 2008: 80). 
Her ne kadar ontolojik inceleme metodu kökünü geçmişten alan bir inceleme yapısına sahipse de içinde yeni metotları çok rahat eritebilen ve anlatı metinlerine bu bakımdan yaklaşabilen bir bakış açısına sahiptir. Kendince kurduğu ana birimler içinde adeta bütün yöntemlerden faydalanabilecek bir niteliktedir. Anlambilim, edimbilim, yapısalcılık, göstergebilim, hermenuötik, anlatı bilimi gibi son zamanlarda kullanılan inceleme tekniklerini içinde eritebilmekte ve onların verilerinden faydalanabilmektedir (Erdem, 2007: 255).

Ontolojik analiz metodu ön yapı ve arka yapı olmak üzere iki ayrı ontik bölüme ayrılır. Ön yapı bir bakıma metnin görünüşünü, şeklini ele alır. Arka yapı metnin dört ayrı bölümünün olduğu varsayımından hareket eder: Birinci aşama semantik tabakadır. Kelimelerin anlamları ile sözcüklerin göndergeleri arasındaki bağ bu katmanda incelenir. İkinci tabaka olan, obje tabakası şiire esas girişin yapıldığı tabakadır. Bu kısımda, şiirin derinliklerine nüfuz edilebilir. Açıklama ve izahlarla şiir tahlil edilir. Üçüncü tabaka olan karakter tabakasında şairin bakış açısı ile şiir arasındaki bağlantı ele alınır. Şairin içindeki duyguları yansıtması dikkati çeker. Şiire mana olarak bakıldığında, şairin hayatıyla şiir arasında bağlantı irdelenir. Son katman kader tabakası olarak isimlendirilmiştir. Bu bölüm varlığın tinsel boyutunu oluşturmasının yanında eser hakkında değerlendirme yapılabilecek en genel bölümdür. Aşă̆ıdaki tablo ontolojik metodu şekilsel olarak özetlemektedir.

\begin{tabular}{|c|c|}
\hline \multicolumn{2}{|c|}{ Şiirin iç ve dış yapısı ${ }^{2}$} \\
\hline $\begin{array}{c}\text { Ön yapı } \\
\text { harfler, heceler, } \\
\text { kelimeler... } \\
\text { ölçü, âhenk, } \\
\text { redif, kâfiye } \\
\text { mısra-beyit yapısı } \\
\text { (Şiirin varlığıyla } \\
\text { duyulan, } \\
\text { algılanan, } \\
\text { görülen maddî } \\
\text { yapısına ait olan her şey) }\end{array}$ & $\begin{array}{c}\text { Arka yapı } \\
\text { 1. Semantik (Anlam) Tabaka } \\
\text { a.Kelime (Cocnitiv ) Semantiği b.Cümle Semantiği } \\
\text { (Sentaks) } \\
\text { 2. Obje (Nesne) Tabakası } \\
\text { Anlamın yoğun olduğu bölüm. Anlamı ağırlıklı olarak } \\
\text { taşıan } \\
\text { kelimeler. } \\
\text { 3. Karakter Tabakası } \\
\text { Şâirin ruh dünyası hakkında bilgiler, kişiliği, hayata } \\
\text { bakış açısı... } \\
\text { 4.Alınyazısı (Kader) Tabakası } \\
\text { Üçüncü tabakadaki tespit ve tanımlamaların çevre ve } \\
\text { bütün insanlık için genelleştirilmesi. }\end{array}$ \\
\hline
\end{tabular}

Başta ontolojik yöntem olmak üzere birçok modern yaklaşım klasik edebiyata hem bedii olarak hem de mana olarak bir şeyler katmıştır. Mezkur teknikler sayesinde klasik metne farklı bir göz ile bakılmış, araştırmacılara farklı ufuklar kazandırılmıştır.

Ele aldığımız mersiye 7 bentten oluşmuş, her bendin konusu farklı olayları belirtse de hadisede tek bir olay örgüsü mevcuttur. Şair, birinci bentte şehzadenin ölümü, öldürülüş sebebi ve entrikalar üzerinde durmuştur. İkinci bentte idam hadisesinin ne şekilde cereyan ettiği, üçüncü bentte şehzadenin ölümüne insanların matem tutması, dördüncü bentte bu ölümün müsebbipleri, beşinci bentte cinayetin nasıl işlendiği, altıncı bentte şehzadenin ölümünü kabulleniş ve şairin teslimiyetçi bir ruh haline bürünmesi ve son bentte ise Şehzade Mustafa için güzel temenniler ve duaların edilmesi söz konusudur. Gencay Zavotçu bu mersiye ile ilgili şu fikirleri dile getirir:

\footnotetext{
2 Bu tablo Yavuz Bayram’ın Ontolojik Analiz Metodu ve Bir Uygulama adlı çalışmasından alınmıştır.
} 
Mersiyenin asker ve sivil kesim arasında geniş yankı uyandırmasının temelinde Yahyâ Bey'in mersiyedeki korkusuz ve yürekli tavrı olduğu söylenebilir. Toplumda geniş bir yankı uyandıran mersiye devlet yöneticileri tarafından askeri isyana teşvik eden bir çıkış, bir başkaldırı aracı olarak nitelenir. Yahyâ Bey o zamana kadar bir mersiyede söylenememiş sözleri dile getirir, her şeyi göze alarak şehzâdenin, sadrazamın da etkili olduğu asılsız bir kurgu sonucu öldürüldüğünü söyler. Hatta, sitem-i Rüstem tamlamasıyla açıkça bu ölümün sadrazamın düşmanlığı sonucu gerçekleştiğini belirtir (Zavotçu, 2007:73).

Şiirde ön yapının vazgeçilmez unsurlarından olan aruz, dizemi sağlamakla beraber redif ve kafiyedeki ses ritminin belirlenmesinde önemli rol oynar. Şair, mersiyeyi aruzun mefâilün /feilâtun/ mefâilün/ feilün (fa'lün) kalıbıyla yazmıştır. Müctes bahrine ait bu kalıpta, Taşlıcalı’nın, mersiyede itibar ettiği aruz kahıbının ahenkli bir şekilde dizem değerlerini yansıttığı görülür. Şair mersiyede yükselip alçalan dizem değerlerine sahip bir aruz kahıbını kullanarak Şehzade Mustafa'nın idamı sonrasında ruhunda yaşamış olduğu acı ve kederi bu vezinle ifade etmiştir.

Mersiyenin birinci bendinde Aruz ölçüsü ile ilgili aşağıdaki terimlerin sayısı saptanmıştır.

\begin{tabular}{|c|c|c|}
\hline İmâle & Zihâf & Vasl \\
\hline 11 adet & 1 adet & 4 adet \\
\hline
\end{tabular}

Birinci bentteki selenî değerleri göz önünde bulundurduğumuzda 'an' ve 'ı' harflerinin Taşlıcalı tarafından sıkça tekrarlandığını görürüz. Ele aldığımız mersiyede Şehzade Mustafa'nın, şiirin anahtarı konumunda olduğunu söyleyebiliriz. Mersiyede ses ve anlamın odak noktası onun ölümüne duyulan hüzün ve feryattır.

Mersiyelerde kafiye olarak kullanılan sesler arasında özellikle üzüntüyü vurgulayanlar dikkati çekmektedir. En çok kullanılan "â- âb- âh- ân- et- în" tam kafiye örnekleridir. Bunlardan özellikle âh kafiyesi hemen daima ölenin arkasından yakınlarının üzüntülerini yansıtan ifadelerle verilmiştir (Öner, 2008:7). Şehzâde Mustafa mersiyesinde ise "â, ân" kafiyeleri ön plandadır.

Şiirde ekseri tam ve zengin kafiye kullanılmıştır. Redifler ve aliterasyonlar, şiirin ahengini sağlayan en önemli unsur olmuştur.

Şiirin kafiye örgüsü şöyledir:

Birinci bend: aa / aa / aa / aa / aa / $\mathrm{xx}$

İkinici bend: $\mathrm{bb} / \mathrm{bb} / \mathrm{bb} / \mathrm{bb} / \mathrm{bb} / \mathrm{xx}$

Üçüncü bend : $c c / c c / c c / c c / c c / x x$

şeklinde sıralanmaktadır.

Birinci bendin kafiye değeri ise şöyledir:

$\begin{array}{lll}- \text { yanı } & - \text { an } & \text { tam kafiye } \\ \text {-Hanı } & -1 & \text { harfi redif } \\ \text {-divânı } & - \text { ân } & \text { zengin kafiye } \\ \text {-Osmânı } & -1 & \text { harfi redif }\end{array}$




$\begin{array}{lll}\text {-meydânı } & \text {-ân } & \text { zengin kafiye } \\ \text { - devrânı } & -1 & \text { harfi redif } \\ \text {-pinhânı } & \text {-ân } & \text { zengin kafiye } \\ \text {-hicrânı } & -1 & \text { harfi redif } \\ \text {-cânı } & - \text { ân- } & \text { zengin kafiye } \\ \text {-erkânı } & -1 & \text { harfi redif } \\ \text {-mâcerâyı gözüm } & \text {-gözüm } & \text { redif } \\ \text {-bu râyı gözüm } & \text {-râyı } & \text { zengin kafiye }\end{array}$

Şiirde vezin ve kafiyeden sonra ritmi tesis eden unsur, ses tekrarlarıdır. Seslerin belli aralıklarla tekrar edilmesiyle şiir, musikiye yaklaşır ve ahenk yönünden çekici bir atmosfere bürünür. (Macit, 2005: 51). Şairin ses tekrarlarını asonans ve aliterasyon ile yaptığını açıkça görebilmekteyiz.

Asonans, aynı ünlünün bir yahut birden çok mısrada birkaç kez tekrar edilmesi olarak tanımlanabilir. Bahsettiğimiz bu periyodik tekrarlar aynı mısra ya da beyitlerde olabileceği gibi metnin tamamına yayılmış olabilir. Genellikle yan yana duran seslerin hoş bir ahenk etkisi yarattığı ve şiirsel melodinin oluşumuna önemli ölçüde katkı sağladığı söylenebilir. Çünkü ünlü sesler sözcüklerin veya hecelerin bir bakıma ruhudur ve nefes alıp veren parçalarıdır (Çetin, 2008: 240).

Üzerinde tetkik ettiğimiz çalışmada Taşlıcalı Yahya'nın, şiirde ritmi sağlarken ünlü ve ünsüz tekrarlarından yararlandığını; mana ile uyum içerisinde olan ünlü ve ünsüzleri tercih ettiğini görebilmekteyiz.

Mersiyenin ilk beytinde 'e' ünlüsü yedi, “a” ünlüsü yedi, 'ı' ünlüsü ise altı kez kullanılır. Bu üç ünlü haricinde olan beş ünlünün beyitteki toplam saylları yedidir. Bir başka ifadeyle beyitte bulunan yirmi yedi ünlüden, yirmisini 'a-ı-e' harfleri oluşturmaktadır. Birinci bendin bütününe baktığımızda bu üç ünlü harfin toplamının, diğer ünlü harflerin toplamının iki katı kadar olduğu açıktır.

\begin{tabular}{|c|c|c|c|c|}
\hline Beyit & "e" harfi & “a" harfi & “” harfi & $\begin{array}{c}\text { "i, o, ö, u, ü" } \\
\text { harfleri }\end{array}$ \\
\hline $\begin{array}{c}\text { Meded meded bu cihânuñ yıkıldı bir yanı } \\
\text { Ecel Celâlîleri aldı Mustafâ Han’ı }\end{array}$ & 7 & 7 & 6 & 7 \\
\hline Birinci bendin toplamındaki ünlü sayısı & 30 & 43 & 34 & 58 \\
\hline
\end{tabular}

Aynı ünsüzlerin bir veya birden fazla mısrada tekrar edilmesi olarak tanımlayabileceğimiz aliterasyon, şiirin müzikal değeri açısından önem arz eder. Kelimelerde sıklıkla kullanılan ünsüz harflerin şiirin genel anlamıyla da paralellik oluşturması ve o yönde çağrışım sağlaması ünsüz ahengi açısından ideal olandır (Çetin, 2008: 239). Birinci bentteki ünsüzlerin ağırlıklı olarak "m-l-d-n" harflerinden oluştuğu, şairin özellikle bu sessiz harflerden yararlanarak ahengi aliterasyonla sağladığı dikkati çeker.

Meded meded bu cihânuñ yıkıldı bir yanı

Ecel Celâlîleri aldı Mustafâ Han'ı

Tulundı mihr-i cemâli bozuldı dîvânı

Vebâle koydılar âl ile Âl-i Osmânı 


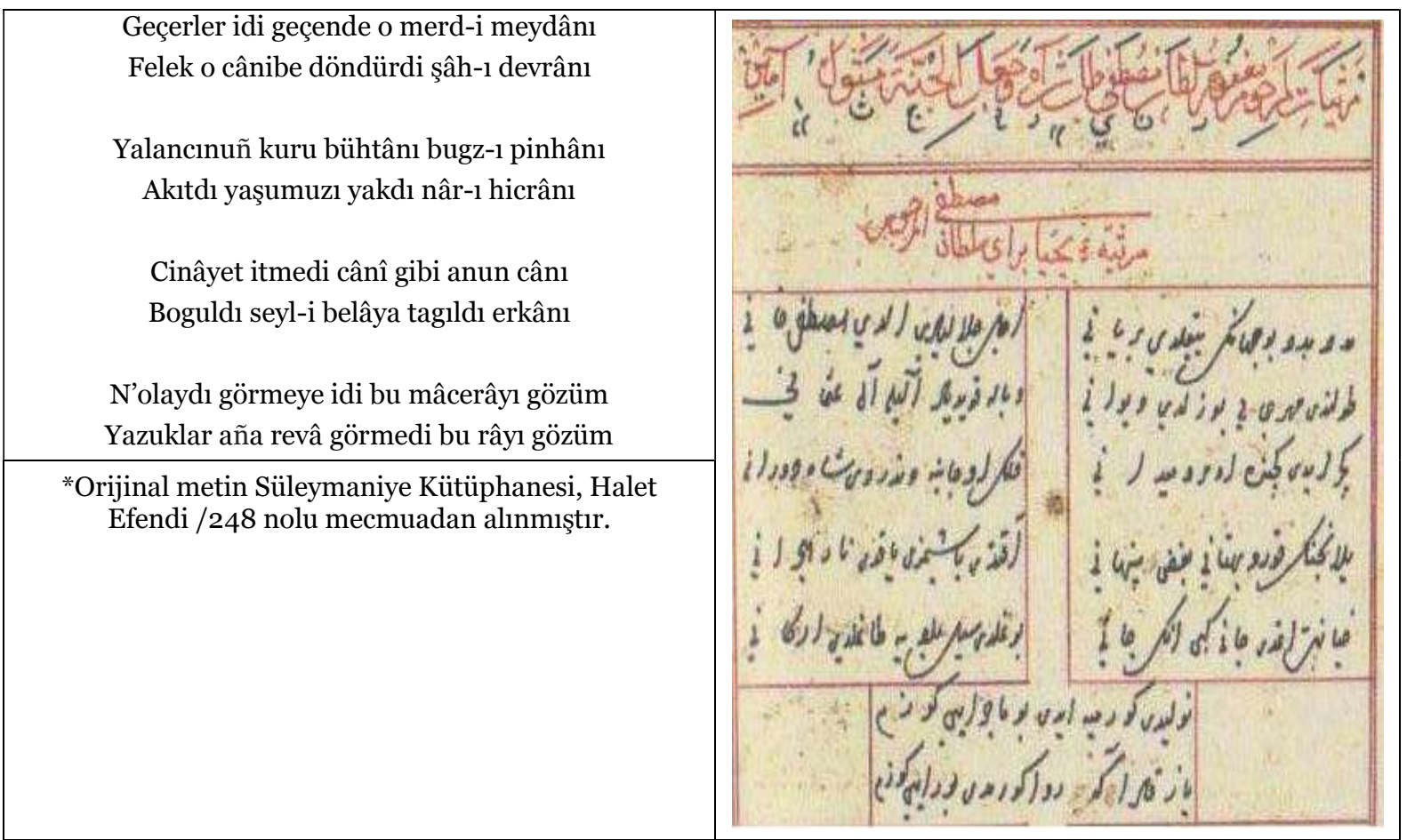

\section{B. Arka yapı/ iç yapı (muhteva)}

Birinci beyit

Meded meded bu cihânun yıkıldı bir yanı Ecel celâlîleri aldı Mustafâ Han'ı

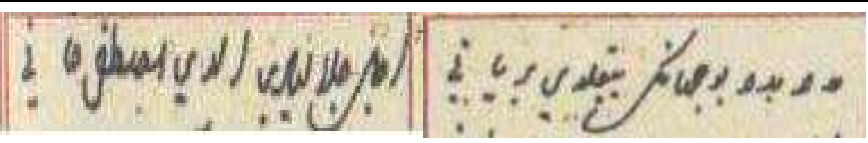

\section{Semantik (anlam) tabaka}

\section{a. Kelime semantiği}

Meded: İmdat

Celâlî: Anadolu'da ortaya çıkan eşkıyaya verilen ad

Cihân : Dünya

Medet kelimesi beyitte "yardım etmek”, celâlî sözcüğü eşkıya, cihan kelimesi ise dünya anlamında kullanılmıştır. Meded, celâlî ve cihân kelimeleri arasında tenasüb sanatı vardır. Dünya (cihan) kötülüğün olduğu yeri simgelemekte, içinde ise celâlî (eşkıya) beslemektedir. İnsan bu kötü mekânda sıkıntıya düştüğünde medet diyerek yardım dilemektedir.

\section{b. Cümle semantiği}

\begin{tabular}{|c|c|}
\hline Metnin orijinal okunuşu & Metnin kurallı düz cümleye çevrilmiş hali \\
\hline $\begin{array}{c}\text { Meded meded bu cihânun yıkıldı bir yanı } \\
\text { Ecel celâlîleri aldı Mustafâ Han’ı }\end{array}$ & $\begin{array}{c}\text { İmdat İmdat! Bu dünyanın bir tarafı yıkıldı. Çünkü ölüm } \\
\text { eşkıyaları Şehzâde Mustafa'yı yakaladı ve boğdu. }\end{array}$ \\
\hline
\end{tabular}




\section{2-3. Obje ve karakter tabakası}

Objeler: Cihan, medet, ecel, celâlî

Şair mersiyeye "medet medet" kelimeleriyle başlamıştır bu da şiirin tam bir mersiye havasında olduğunu gösteriyor. Yahya Bey samimi bir dille Şehzâde Mustafa'yı kaybetmenin acısını dile getirir. Şehzadeye olan yakınlığı sebebiyle onu kaybetmenin hayatında yarattığı boşluktan söz eder. Onun ölümünü dünyanın bir bölümünün yıkılmasıyla bir tutarak mübalağa sanatı yapar. Cihanın yıkılmasından kastedilen bütün insanlıktır. Şehzâdenin ölümü karşısında derin üzüntü duyan insanların içinde bulunduğu ruhsal durum âdeta cihanın yıkılması gibidir. İlk beyitte vurgu Mustafa Han'dır. Ecel, sözlükte; muayyen olan vade, ömrün sonu, hayatn son demi anlamlarna gelmektedir. Yahya Bey eceli, can almaları, her yeri talan etmeleri yönü ile celâliye (eşkıyâ) benzetmiştir (İnce, 2005: 87) .

Yavuz Sultân Selim zamanında Anadolu'da çıan isyana ve daha sonra meydana gelen bu tür isyanlara hep Celâlî isyanları denilmiştir. Bu isyanları müteakip "celâlî” tabiri artık eşkıya-asi kelimeleriyle eş anlamlı hale gelmiştir. Taşlıcalı, şehzâdenin öldürülmesini resmen eşkıyalık olarak nitelendirmiş, bu katliamı yapanları da ecel cellatları olarak görmüştür.

Yahya Bey, medet kelimesini iki defa üst üste söyleyerek hem içinde bulunduğu durumunun mahiyetini psikolojik olarak vurgulamış, hem de tekrir sanatına başvurarak ahengi sağlamıştır. Şairin "ecel" ve "celâlî" arasında bir teşbih kompozisyonu oluştururken her iki ibare arasında "cim" ve "lam" harfinden oluşan müssterek ses değerlerini de göz önünde bulundurması dikkate değer görünmektedir (Şentürk, 2014: 109).

Karakter tabakasına genel olarak baktığımızda psikolojik çöküş görüntüsü veren bir beyitle karşılaşmaktayız. Şaire göre ruhsal olarak bu çöküş aynı zamanda dünyanın da çöküşüne zemin hazırlamıştır. Şair hüzünlü ve aciz bir durumdadır. Bu haliyle yardım istemektedir.

\section{Kader tabakası}

Bu dünyada iktidar gölge bile kabul etmez. Doğadan örnek verirsek aslan iktidarını kaybetmemek, sürüsünün güvenini kanıtlamak için kendi yavrularını bile etkisiz hale getirir. İktidar ihtirası insanlara her şeyi yaptırır, kişinin mantıklı düşünmesinin önünde engel olur.

İkinci beyit

Tulundı mihr-i cemâli bozuldı dîvânı Vebâle koydılar âl ile Âl-i Osmânı

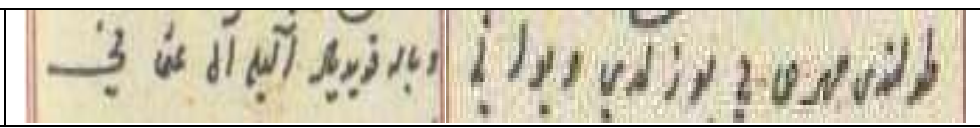

\section{Semantik (anlam) tabaka}

\section{a. Kelime semantiği}

Mihr : Güneş

Tulunmak : Batmak, gözden kaybolmak

Vebâl : Şiddet, azap 
Âl: Hile, düzen

Âl-i Osman: Osmanlı sülalesi

Mihr sözcüğü, mihr-i cemal terkibiyle kullanılmış ve güzel yüzünün güneşi anlamı kazanmıştır. Vebal kelimesi ise günah anlamıyla beyitte geçmektedir.

\section{b. Cümle semantiği}

\begin{tabular}{|c|c|}
\hline Metnin orijinal okunuşu & Metnin kurallı düz cümleye çevrilmiş hali \\
\hline $\begin{array}{c}\text { Tulundı mihr-i cemâli bozuldı dîvânı } \\
\text { Vebâle koydılar âl ile Âl-i Osmânı }\end{array}$ & $\begin{array}{c}\text { Onun güneş gibi parlak olan yüzü battı ve maiyeti } \\
\text { bozuldu. İmparatorluğu hile ile vebal altında } \\
\text { bıraktılar. }\end{array}$ \\
\hline
\end{tabular}

\section{2-3. Obje ve karakter tabakası}

Objeler: Tulındı, mihr-i cemâl, âl, Âl-i Osman, vebâl, divân

Tulınmak fiili batmak, gözden kaybolmak anlamlarına gelmektedir. "Mihr-i cemâl"den kasıt şehzâdenin güneş gibi parlak olan aydınlık yüzüdür. Şaire göre o parlak yüz artık mevcut olmayıp batmıştır. Bu beyitte benzetmeden yararlanarak teşbih sanatı yapılmıştır. Bunun yanında mihr-i cemâl kelimesiyle istiare sanatı yapılmıştır. Bu terkipte kastedilen şehzâdenin yüzü olduğu için açı istiare yapılmıştır. Bunlara ilaveten mihr kelimesinde de dikkatli okunduğunda tevriye sanatını görebiliriz. Mezkûr kelime "güneş" manasına geldiği gibi "sevgi ve şefkat" anlamlarına da gelmektedir.

Güneş her zaman saltanatla bir kabul edilmiştir. İktidarın en üst makamında bulunan kişi güneş gibidir. Şaire göre, şehzade onun gözündeki ve gönlündeki sultandır. Bu beyitte çıkarılacak önemli iki sonuç vardır. Birincisi bu katliama sebep olanların yanlarına bir şeylerin kalmayacağı, ikinci sonuç ise onun ölümüyle bir devrin sonuna gelinmesidir. Şehzadenin öldürülmesine sebep olanlar hem günaha girmiş hem de güneşin batmasına yani Osmanlı’nın çökmesine neden olmuşlardır.

Ele aldığımız beyitte öne çıkan bir başka kavram " âl (hile)"dir. Osmanlı devletinin belki de gerileme sürecinin somut bir başlangıcı olarak düşünülebilecek böylesi mühim bir olayda, şairin diğer bentlerde de "hile" kavramını ısrarla vurgulaması ve Şehzâde Mustafa'nın masumiyetini ön plâna çıkarması manidardır. Bununla beraber -âl- ifadesi "Âl-i Osman" ifadesiyle bir ahenk oluşturmuştur. -âl- hileyi, Âl-i Osman ise hükümdarı temsil etmektedir. Her iki kavramda bu olayda kötü bir şeyleri simgelemektedir. Dolaysıyla her ikisi de günah anlamındaki vebâl kelimesiyle hem sözel hem de mana olarak bir ahenk oluşturmuştur. Âl ile Âl-i Osmân'daki âl kelimesi arasında cinas sanatı vardır.

Taşlıcalı Yahya'ya göre Âl-i Osman yani hükümdar ve üst düzey yöneticiler şehzâdeyi öldürmekle hem vebale giriyor hem de Osmanlı Devleti’nin çöküşüne zemin hazırlıyordu. Bu beyitte "divanın bozulması", "beşinci beyitte "erkanın dağılması" şaire göre şehzâdenin ölümünden dolayıdır. Gerçekten de birçok muharrir ve tarihçi onun ölümünü Osmanlı’nın önce duraklaması akabinde çöküşüne yol açtığını düşünmektedir. 


\section{Kader tabakası}

Alın yazısı tabakasında vebal kavramı ön plandadır. Vebal kelimesi sonunda ceza, şiddet ve azap olan fiil, günah, sorumluluk ve kötü akıbet anlamlarında kullanılır. Vebalde olan kişiler mutlaka bir suç işlemişlerdir. Taşlıcalı, şehzadenin ölümüne yol açan kişileri büyük günah işlemekle itham etmiştir. Zira ona göre şehzade hiçbir cana kıymadığı halde cinayete kurban gitmiştir. Nitekim “ Kim, bir cana veya yeryüzünde bozgunculuk çıkarmaya karşılık olmaksızın (haksız yere) bir cana kıyarsa bütün insanları öldürmüş gibi olur." âyet-i kerimede de (Mâide-32) belirtildiği gibi haksız yere cinayet işleyenlerin günahı çok büyüktür. Şaire göre bu trajedi sonucunda Osmanlı hanedanını kötü akıbet bekleyecektir.

Üçüncü beyit

Geçerler idi geçende o merd-i meydânı

Felek o cânibe döndürdi şâh-ı devrânı

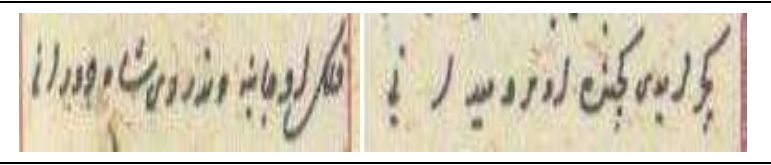

\section{Semantik (anlam) tabaka}

\section{a. Kelime semantiği}

Merd-i meydân: Meydanların yiğidi

Cânib: Taraf, yön

Şâh-ı devrân: Cihan padişahı, zamanın padişahı

Beyitte "merd-i meydân" sözcüğünün göndergesi Şehzade Mustafa, şâh-1 devrân kelimesinin göndergesi Kanuni Sultan Süleyman’dır. Cânib ise feleğin yönünü döndürmesiyle metinde geçmektedir.

\section{b. Cümle semantiği}

\begin{tabular}{|c|c|}
\hline Metnin orijinal okunuşu & Metnin kurallı düz cümleye çevrilmiş hali \\
\hline Geçerler idi geçende o merd-i meydânı & Padişahın yanında o yiğidin sözü geçtikçe onu \\
Felek o cânibe döndürdi şâh-ı devrânı & çekiştirirlerdi. Nihayet devir padişahını felek, onların \\
& yönlendirmek istedikleri tarafa döndürdü. \\
\hline
\end{tabular}

\section{2-3. Obje ve karakter tabakası}

Objeler: Felek, merd-i meydan, cânib, şâh-ı devrân

Felek kelimesi gökyüzü, sema; talih, baht, kader anlamlarına gelir. Divan şiirinde ise genellikle kötü imaj olarak bilinir. Yeryüzünde meydana gelen kötü olayların müsebbibi olarak bilinmektedir. Bundan dolayı şairler feleği suçlamış, şairlerimizin sürekli şikâyet ettiği bir merci haline gelmiştir. Divan şairleri onu, insanın kaderi ve talihini hazırlaması bakımından en şiddetli şekilde itham eder. O yeri gelir zalim olur yeri gelir aldatıcı olur. Bunun sebebini İskender Pala şu şekilde açıllar:

Atlas feleği yirmi dört saatte bir devrini tamamlar. Bu devir (dönüş) doğudan batıya doğru olup, diğer felekleri de döndürür. Diğer feleklerin iki türlü hareketi vardır. Biri Atlas feleği ile birlikte doğudan batıya, diğeri de bunun aksi olarak batıdan doğuyadır. Atlas feleği dönerken diğerlerini de kendi istikametinde dönmeye zorlar. Bu dönüş büyük bir özellik taşır. Kendi istikameti dışında dönüşe zorlanan sekiz felek, insanların talihleri, refah ve mutlulukları üzerinde değişken ve aksi durumlar 
ortaya koyar. İşte felekler üzerine şikâyet etmenin nedeni budur. "Kahpe felek, dönek felek" gibi şikâyetlerin aslı da dokuzuncu felek olan Atlas feleğinin ters dönüsü sebebiyledir. Dokuzuncu felekten sonra Allah ilminin başlaması, insanların kaderlerinden dolayı ettikleri şikâyetleri bu feleğe yüklemelerine neden olmuştur. (Pala, 1995:165).

Taşlıcalı Yahya, bu beyitte asıl suçlu olarak gördüğü padişahı imalı bir şekilde eleştirir ancak bütün suçu feleğe yükler. Taşlıcalı’ya göre padişahın yönünü döndüren felektir.

Divan şiirindeki mersiyelerde müteveffa kişiler ile ilgili methiyeler geniş yer bulur. Şahsın vefatı akabinde keder verici içerikli metinlerin istisnai olarak sadece övülecek vasıflara sahip kişiler için yazılması tesadüf değildir. Mersiyesinin bütününde Şehzade Mustafa'nın kişisel özelliklerini yücelten, onu istisnai bir kahraman olarak lanse eden bölümler oldukça fazladır. Bu beyitte de şehzadenin meydanların yiğidi olarak görülmesi dikkatimizi çekmektedir.

Ele aldığımız beyitin edebi sanatlar açısından da zengin olduğu görülür. Merd-i meydân ve Şâh-ı devrân terkiplerinde istiare sanatı mevcuttur. Şairin merd-i meydân kelimesini şehzâde için kullanmıştır. Ona göre Mustafa meydanların yiğididir. Şâh-ı devrân kastettiği ise Padişah Sultan Süleyman'dır. He iki imgede de açık istiare mevcuttur. Bunun yanında beyitte anlam olarak bir tezatlık söz konusudur. Bir taraftan yücelttiği şehzâde, diğer taraftan ince dokundurmalarla hicvettiği hükümdar vardır. Şairin, bu olaya müdahil olan feleğe ve padişaha sitemi vardır.

\section{Kader tabakası}

Klasik edebiyatımızda felek, daha çok şikâyet yerine kullanılır. Bu beyitte de alın yazısı tabakasını oluşturmaktadır. Ne kadar güçlü, ne kadar sevilirsen sevin, hiçbir zaman feleğin hükmünü bertaraf edemezsin. Kaderinde yazılı olan hükme tabisin ve onu değiştiremezsin. Şairin de vurguladığı gibi birey felek karşısında çaresiz olup, tamamıla akıbetine teslim olmaktadır.

Dördüncü beyit

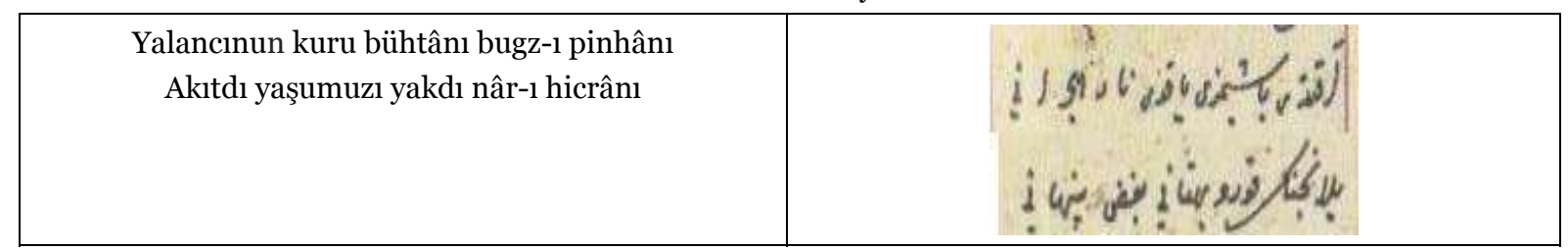

\section{Semantik (anlam) tabaka}

\section{a. Kelime semantiği}

Bühtân: Yalan, iftira

Buğz-1 pinhân: Gizli nefret

Nâr-ı hicrân: Ayrllık ateşi

Buğz-ı pinhân, Şehzade Mustafa'yı sevmeyen kişilerdir. Bu kişiler şehzadeye iftira atarak, onun ölümüne sebep olmuşlardır. Onun ölümü ise nâr-ı hicrana benzetilmiştir.

\section{b. Cümle semantiği}




\begin{tabular}{|c|c|}
\hline Metnin orijinal okunuşu & Metnin kurallı düz cümleye çevrilmiş hali \\
\hline $\begin{array}{c}\text { Yalancınun kuru bühtânı bugz-ı pinhânı } \\
\text { Akıtdı yaşumuzı yakdı nâr-ı hicrânı }\end{array}$ & $\begin{array}{c}\text { Yalancının kuru iftirası ve gizli düşmanlığı } \\
\text { gözümüzün yaşını akıttı, gönlümüzde ayrılık ateşi } \\
\text { yaktı. }\end{array}$ \\
\hline
\end{tabular}

\title{
2-3. Obje ve karakter tabakası
}

Objeler: Yalancı, bühtân, bugz-ı pinhân, nâr-ı hicrânı,

Taşlıcalı'nın yalancı kelimesinden kastettiği Rüstem Paşa'dır. Şair burada açı istiare sanatı yaparak Rüstem Paşa'yı yalan söylemek ve entrika kurmakla itham ediyor. Ona göre şehzâde, Rüstem’in iftiralarına kurban gitmiştir. Seferde bizzat bulunan ve yaşanan trajedinin içinde olan Yahya Bey, mersiyesinde hem kendinin hem de o dönemin kamuoyunun görüşlerini yansıtmaktadır. Yahya Bey, ekseri kamuoyunun üzüntüsünü ve kederini aktardığı mersiyesinin Şehzade Mustafa'nın öldürülmesini, ona kurulan mektup tuzağı ve çıkarılan yalan haberlere dayandırır.

\begin{abstract}
Hürrem Sultan, Damat Rüstem Paşa ile baş başa veriyor, arada mani teşkil eden, Kanuni'den sonra saltanat namzedi Şehzâde Mustafa'yı bertaraf etmenin hilelerini araştırıyordu... Kanuni, Rüstem Paşa'yı Acem seferine memur etmişti. Ordular, Trakya'dan Anadolu'ya geçiyor, şehzâdeler hazırlanıyordu. İşte bu sırada ordu içinde bir dedikodu yayıldı... Bir sabah sipahi oğlanları ağası Şemsi Ağa, İstanbul'a çıkageldi. Derhal saraya koştu. Padişahın ayaklarına kapandı, koynundan çıkardığı bir telhisi, Kanuni'ye sundu. Bu telhis Rüstem Paşa'dandı. Şehzâde Mustafa'nın taht ve saltanat uğrunda isyana hazırlandığını haber veriyordu. Rüstem Paşa'nın telhisinden sonra padişah yavaş yavaş zehirlenmiş, nihayet oğlunun kendi saltanatına göz diktiğine inandırılmıştı (Yeşim, 1969: 38).
\end{abstract}

Kuru bühtân kelimesi boş söz, iftira anlamında kullanılmıştır. Bu ifade de mecaz sanatının yanında tezat sanatı da hâkimdir. İkinci beytin başındaki akıtmak fiili ile kuru kelimesi arasında bir zıtlık vardır. Bugzı pinhân, nâr-ı hicrânı terkiplerinde de teşbih sanatı söz konusudur. Ayrıca diğer beyitlerde olduğu gibi geçmiş bir olay hakkında bahsedildiği için telmih sanatı da bu beyitte vardır.

İftira ve nihan bir kıskançlık şehzâdenin trajik ölümüne zemin hazırlamıştır. Taşlıcalı, Şehzâde Mustafa hakkında uydurma bilgilere ulaşmış ve bu ölümün yalanla beslenen bir kurgu olduğuna inanmıştır. Şairin içinde bulunduğu ruh hali oldukça kötüdür. Taşlıcalı, Rüstem Paşa'yı yalan söylemekle itham ediyor ve ona derin bir öfke duyuyor.

\section{Kader tabakası}

Divan şiirinde iftira atan kişiler; cahilliği, kabalığı, çirkin tutum ve davranışları, kıskançlığı, kibri, inadı, şerri sevmesi, yalan söylemesi, zulmü, hak tanımazlığı, kadir ve kıymet bilmemesi, değer vermemesi gibi hep olumsuz kişilik özellikleriyle anılmıştır ancak bütün bu menfi kusurlarına rağmen çoğu zaman yaptıkları gıbbetler ve iftiralar işe yarıyordur. İftira atan kişiler amaçlarına bazen ulaşır, istediklerini kısmen de olsa elde ederler.

Beşinci beyit

Cinâyet itmedi cânî gibi anun cânı

Boguldı seyl-i belâya tagıldı erkânı

\section{Semantik (anlam) tabaka}




\section{a. Kelime semantiği}

Cânî : Katil

Cân : Hayat

Erkân: Subaylar, askerler

Seyl-i belâ : Bela seli

Tagılmak : Dağılmak

Erkan sözcüğü her ne kadar ordu anlamına gelse de beyitteki göstergesi şehzadenin yakın çevresidir. Câni kelimesi beyitte katil anlamında kullanılmış, bir canlıyı yok etmiştir.

\section{b. Cümle semantiği}

\begin{tabular}{|c|c|}
\hline Metnin orijinal okunuşu & Metnin kurallı düz cümleye çevrilmiş hali \\
\hline $\begin{array}{l}\text { Cinâyet itmedi cânî gibi anun cânı } \\
\text { Boguldı seyl-i belâya tagıldı erkânı }\end{array}$ & $\begin{array}{c}\text { Zavallı şehzâde, caniler gibi bir cinayet işlememişken, belâ } \\
\text { seline düşüp boğuldu. Yanında bulunan bütün yakınları } \\
\text { darmadağın oldu. }\end{array}$ \\
\hline
\end{tabular}

\section{2-3. Obje ve karakter tabakası}

Objeler: Cinâyet, cânî, cânı, seyl-i belâ

Cinâyet ve cânî kelimeleri aynı kökten türedikleri için iştikak sanatı yapılmıştır. Cânî kişiler cinayet işleyerek bir cana kıymışlardır. Mısrayı başka bir şekilde değerlendirdiğimizde "O bir cânî gibi cinayet işlememiştir” anlamı çıkar. Yani şair kelimelerin anlamları üzerinde kinayeli bir ifade kullanmıştır."Cânı̂” ve "cânı" kelimelerin yazılışları aynıdır; fakat okunuşları farklı olduğu için bu kelimeler arasında cinâs-ı hattî sanatı vardır. Cinâyet, cânî, cân kelimeleri ile boğulmak ve sel kelimeleri arasında bir uygunluk olduğundan burada tenâsüb sanatı söz konusudur.

Mersiyenin ikinci dizesinde şehzadenin bela selinde boğulduğundan ve ordunun dağılmasından söz etmektedir. Şehzadenin öldürülmesi sonucu devlet erkanın yıkıldığı, ordunun bozulduğu, mersiyenin çoğu beytinde görülmektedir. Seyl-i bela tamlamasında teşbih sanatının olduğunu açıkça görebiliyoruz. Bela bu mısrada sele benzetilmiştir. Şehzâdenin bela selinde boğulması mecazî anlamının yanında gerçek anlamında kullanılmıştır. Nitekim şehzâdenin ölümü boğularak olmuştur.

...Mustafa hemen teslim olmadı ve uzun bir süre cellatlarla mücadele etti. Hatta bir aralık kurtulmaya dahi muvaffak oldu. Fakat, saray hademelerinden pehlivan Zal Mahmud üzerine atılp basttrdı ve böylece boynuna kemendi geçirip şehzâdeyi boğdular. (İsen, 1994: 80). Görüldüğü gibi şehzadenin ölümü boğularak olmuştur. Şair de bu boğulmak kelimesini bu konseptte kullanmıştır.

Diğer beyitlerde olduğu gibi bu beyitte de bir çöküş psikolojisi hâkimdir. Beytin tamamında hüzün ve karamsarlık vardır. Şairin içinde bulunduğu ruh hali kelime seçimlerini bile etkilemiş, vurguya şekil vermiştir. 


\section{Kader tabakası}

Masum insanların da suçsuz yere öldürüleceği beytin kader tabakasını oluşturur. Taşlıcalı’ya göre şehzade bir cani gibi cinayet işlemediği halde cinayete kurban gitmiştir. Olayın sorumluları ise günlük hayatlarına normal bir şekilde devam etmişlerdir. Kendi suçlarından haberi olmayan kişiler, suçsuz insanları kendi bilinçaltında suçlu olarak gösterir ve onları cezalandırır.

Altıncı beyit

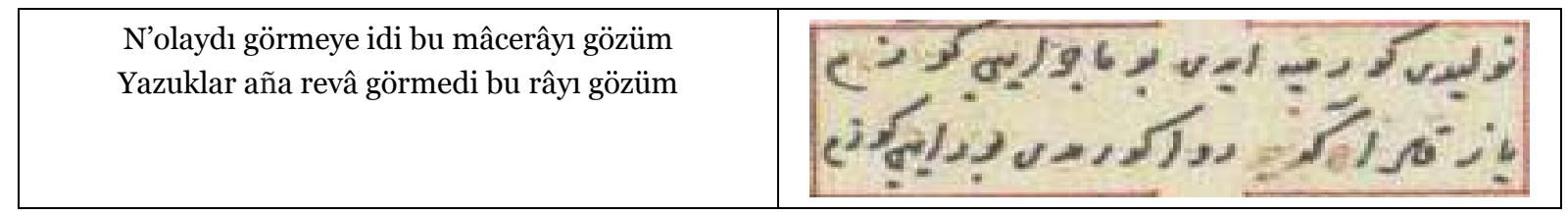

\section{Semantik (Anlam) Tabaka}

\section{a. Kelime semantiği}

Revâ : Uygun

Rây: Fikir

Mâcerâ : Olay

Revâ kelimesi beyitte yakıştırmak anlamında; rây sözcügü ise bir hüküm verme anlamlarında kullanılmıştır.

\section{b. Cümle semantiği}

\begin{tabular}{|c|c|}
\hline Metnin orijinal okunuşu & Metnin kurallı düz cümleye çevrilmiş hali \\
\hline $\begin{array}{c}\text { N’olaydı görmeye idi bu mâcerâyı gözüm } \\
\text { Yazuklar aña revâ görmedi bu râyı gözüm }\end{array}$ & $\begin{array}{c}\text { Keşke bu olayı gözüm görmemiş olsaydı. Şehzâde } \\
\text { hakkındaki hükmü ve uygulanan cezayı adalete uygun } \\
\text { görmedim. }\end{array}$ \\
\hline
\end{tabular}

\section{2-3. Obje ve karakter tabakası}

Objeler: N’olaydı, gözüm, revâ, rây

Mersiyelerde ölenin ardından hissedilen derin üzüntü dile getirilmeye çalışılır. Ölüm karşısında hissedilen duygulardan biri de şaşkınlıktır. Şair, değer verdiği kişinin ölümüne bir türlü inanmak istemez, ölümü kabullenmekte zorlanır (Çavuş, 2008: 133). Şair son beyitte derin üzüntünün vermiş olduğu şaşkınlık ve inkâr içindedir. "Keşke gözüm bu olayı görmeseydi..." diyerek hadiseyi halen kabullenmek istemediğini açıkça göstermektedir. Bu mısrada hadiseyi görmemiş olmayı tercih ettiğini dile getirmektedir.

İlk mısradaki gözüm kelimesinin tevriye sanatıyla beraber kullanıldığı dikkatimizi çeker. Birinci anlam olarak "gözüm" kelimesi gözüm kadar değerli olan şehzâdem olarak algılanabilir. İkinci anlam olarak ise "ne olurdu şehzâdem bunları görmeseydi.” Anlamı çıkar. İkinci mısrada ise şair şehzâdeye yapılanları 
ona layık görmediğini, bütün bu muamelelere maruz kalmayı hak etmediğini vurgulamaktadır. A. Atilla Şentürk ise eserinde bu mısra için görüşünü şöyle ifade eder:

"Yazıklar olsun! Ona -ra-yı gözüm revâ görmedi” cümlesindeki -râ- kelimesi “ „ “ harfinin okunuşu daha doğrusu Arapçadaki ismidir. Rüstem’e râ’yı revâ görmedim demek bir bakıma -Rüstem’e râ harfi fazladır- demek olur. Rüstem'den râ çıkarsa geriye zulüm anlamında sitem kalır. Yani şair okuyucuya Rüstem’e râ harfi fazladır, bence o sitemin, zulmün ta kendisidir mesajını vermektedir. (Şentürk, 2014: 122).

Bu beyitte cinas sanatı, aliterasyon ve telmih sanatları da söz konusudur. Mısra sonlarındaki gözüm kelimeleri cinas sanatını, aynı şekilde göz isminin beyit içerisinde çokça kullanılması ve bundan oluşan ahenk sonucu aliterasyon sanatı oluşmuştur. Eser geçmişte yaşanılan bir olay örgüsünden alındığı için bu beyitte telmih sanatı vardır.

Birinci bendin son beyitinde, şehzadenin ölümü şair tarafından halen kabullenilmemiştir. Bu inkâr davranışının yanında sitem ve öfke devam etmiştir. Şehzadenin ölümü, şairi paramparça etmiş, onun yüreğinde hiçbir duygu bırakmamıştır.

\section{Kader tabakası}

Ölüm karşısında çaresizlik vardır. Her konuda çözüm bulmaya çalışan insan, ölüm karşısında tam olarak acizdir. Teslimiyet dışında yol bırakmaz ölüm. Ölümün kaçınılmaz bir son olduğu konusundaki fikir birliği dinlerin ikna ediciliğinin yanında, ilk insandan buyana yaratılan bütün insanların öldüğünün görülmesi gerçeğine dayanır. Çok değer verilen birinin ölümü zamanla kabullenilebilecek bir olgudur. Sevilen birinin kaybedilmesi kişide derin üzüntü bırakır, ilk zamanlarda bunu kabullenmek çok güç olur.

\section{Sonuç}

Modern inceleme yöntemlerinden biri olan ontolojik analiz metodu, çağdaş edebiyata uygulanmasının yanında klasik edebiyatımızda da pratiğe dökülmüştür. Başta ontolojik yöntem olmak üzere birçok modern yaklaşım klasik edebiyata hem bedii olarak hem de mana olarak bir şeyler katmıştır. Mezkur teknikler sayesinde klasik metne farklı bir göz ile bakılmış, araştırmacılara farklı ufuklar kazandırılmıştır. Günümüz araştırmacıları, metin tenkitçileri klasik edebî ürünleri ontolojik yöntemle incelerken, gerek iç yapı gerek dış yapı özellikleri bakımından, bu yöntemin uygulanabilirliğinin mümkün olduğunu somut bir şekilde ileri sürmüştür.

Ön yapıda şiirin şekil olarak analizi üzerinde durulur. Arka yapıda ise şiirin anlamsal boyutu ele alınmış ve dört katmanda incelenmiştir. Birinci katman olan semantik tabakada, kelimelerin anlamları ile sözcüklerin göndergeleri arasındaki bağ incelenirken, şiirin derinliklerine nüfuz eden ikinci katmanda obje esastır. Üçüncü tabaka olan karakter tabakasında şairin dünya görüşü ve ruhsal durumunun şiire yansıması aksederken, son tabaka olan kader katmanında ise varlığın tinsel boyutu ele alınır.

Şehzâde Mustafa'nın idamı zamanla edebî ürünlerin muhtevasını oluşturmuştur. Bu çalışmada Taşlıcalı Yahya Bey'in Şehzade Mustafa için yazmış olduğu mersiyeyi ontolojik metotla ele aldık. Mersiyedeki birinci bentten yola çıarak şairin psikolojik dünyası, semantik bölümü, kelimelerin algısal olarak karşılığı obje ve karakter imajı ve son olarak da kader katmanı eserde tetkik edilen belli başlı konulardır. Şair mersiyeyi öznel bir üslupla ele almış, objektif değerlendirmelerden kısmen de olsa uzaklaşmıştır. 
Taşlıcalı Yahya kelimeleri seçkin kullanmış, başta kinaye ve teşhis sanatı olmak üzere birçok edebi sanattan yararlanmıştır.

\section{Kaynakça}

Bayram, Y- Erdemir, A. (2008). "Manzum Metinlerin Tahlilinde Ontolojik Yöntem”. Prof. Dr. Mustafa Özbalcı Armağanı, Ankara: Birleşik 76- 89.

Bayram, Y. (2003). Ontolojik Analiz Metotu ve Bir Uygulama. Adana: Yom Sanat, (12), 12-16.

Bingöl, U. (2019). Ontolojik Metin Tahlili Hakkında Bazı Tespitler. RumeliDE Dil ve Edebiyat Araştırmaları Dergisi, (14), 144-153.

Çavuş, Z. (2008). Türk Edebiyatında Mersiyenler. A.Ü. Türkiyat Araştırmaları Enstitüsü Dergisi (38), 131-138.

Çetin, N. (2008). Şiir Çözümleme Yöntemi. Ankara: Öncü.

Erdem, M. D. (2007). Ontolojik İncelemeye Dehhânî̉nin “Eyledi” Redifli Gazeli Örneğinde Yapısalcı Bir Bakış. Turkish Studies ,(3), $254-273$.

İçli, A. (2009). Necati’nin Bir Şiirinin Ontolojik Analiz Yöntemiyle İncelenmesi”, Journal of New World Sciences Academy (4)

İnce, S. (2005). Taşlıcalı Yahya Bey Divanı’ndaki Soyut Kavramlar, İstanbul Üniversitesi Sosyal Bilimler Enstitüsü Yayımlanmamış Yüksek Lisans Tezi, İstanbul.

İsen, M. (1994). Acıyı Bal Eylemek, Ankara: Akçă̆.

Macit, M. (2005). Divan Şiirinde Âhenk Unsurları, İstanbul: Kapı.

Mengi, M. (1983). Eski Edebiyatımızın Mersiyelerine Toplu Bir Bakış. Türk Dili ve Edebiyatı Araştırmaları Dergisi (2)

Öner, G. (2008). Mersiyelerde Ölüm ile İlgili Benzetme ve Kullanımlar, Sakarya Üniversitesi Sosyal Bilimler Enstitüsü Yayımlanmamış Yüksek Lisans Tezi, Sakarya.

Öztürk, F. (2007). Osmanlı Şiirine Sanat Ontolojisiyle Yaklaşmak Üzerine, Turkish Studies (4),680684.

Pala, İ. (1995). Ansiklopedik Divan Şiiri Sözlüğü İstanbul: Akçă̆.

Şentürk, A. A. (2014). Kanuni Hicviyesi yahut Yahyâ Beg'in Şehzade Mustafa Mersiyesi. İstanbul: Büyüyen Ay.

Tökel, D. A. (2007). “Divan Şiirine Modern Metin Çözümleme Yöntemlerinden Bakmak” Turkish Studies (2), 535-555.

Tunalı, İ. (2002). Sanat Antolojisi. İstanbul: İnkılap.

Turan, S.- Akgül, A. (2012), Sâfînin Kerbelâ Mersiyesi Üzerine Bir Tahlil. Türk Kültürü ve Hacı Bektaş Veli Araştırma Dergisi, (64), 31-42.

Yeşim, R. Ş. (1969). “Kanunînnin Çocukları Nasıl Öldürüldü?”, Hayat Tarih Dergisi (1)

Yeter, G. B. (2010). Ontolojik Analiz Metoduyla Yunus Emre'nin Bir Şiirinin İncelenmesi. Mukaddime, (3),141-154.

Yiğiz, U . (2018). Kerbelâ'nın En Küçük Şehîdi -Alî-yi Asgar- İçin Yazılmış Bir Mersiye. Hikmetakademik edebiyat dergisi (Online) , (8) , 204-228.

Zavotçu, G. (2007). Bir Ölümün Yankıları ve Yahya Bey Mersiyesi, A. Ü. Türkiyat Araştırmaları Enstitüsü Dergisi, (33), 69-80. 